\section{Effect of Metalloproteinase Inhibitors on the Microtensile Bond Strength of Composite Resin to Er:YAG Laser-Irradiated Dentin}

Beatriz Carlos Correa ${ }^{1}$, Rodrigo Galo ${ }^{1}$, Camila Scatena ${ }^{2}$, Maria Cristina Borsatto ${ }^{1}$ Aloísio Oro Spazzin ${ }^{3}$, Silmara Aparecida Milori Corona ${ }^{1}$, Daniel Galafassi $^{3}$

\author{
'Department of Pediatric Dentistry, \\ School of Dentistry of Ribeirão \\ Preto, USP - Universidade de São \\ Paulo, Ribeirão Preto, SP, Brazil \\ ${ }^{2}$ Department of Pediatric Dentistry, \\ FSG - Faculdade da Serra Gaúcha, \\ Caxias do Sul, RS, Brazil \\ ${ }^{3}$ Department of Restorative Dentistry, \\ School of Dentistry, IMED - Faculdade \\ Meridional, Passo Fundo, RS, Brazil \\ Correspondence: Daniel Galafassi, \\ Rua Senador Pinheiro, 304, 99070- \\ 220 Passo Fundo, RS, Brasil. \\ Tel: +55-54-3045-6100. e-mail: \\ danielgalafassi@imed.edu.br
}

Key Words: Er:YAG laser, dentin, bond strength, degradation.

\begin{abstract}
This study evaluated the effect of matrix metalloproteinase (MMP) inhibitors - 2\% (CHX) and sodium fluoride (NaF) (5000 ppm) - on microtensile bond strength ( $\mu$ TBS) of composite resin to Er:YAG laser-irradiated dentin after chemical degradation of the bond interface. The occlusal surface of forty sound human molars was removed exposing the dentin surface $(n=10)$, which was polished, irradiated with Er:YAG laser, acid etched and dried. Twenty specimens were rewetted with $2 \% \mathrm{CHX}$ (control group) and 20 were rewetted with $\mathrm{NaF}$ (5000 ppm). The adhesive system was applied and a 4-mm-high plateau of light-cured composite resin was built up. Resin-dentin sticks were obtained with a rectangular cross-sectional area $\left(0.8-1 \mathrm{~mm}^{2}\right)$ and were either stored in water at 37 ${ }^{\circ} \mathrm{C}$ for $24 \mathrm{~h}$ or submitted to chemical degradation. For chemical degradation, they were immersed in $10 \% \mathrm{NaOCl}$ aqueous solution for $5 \mathrm{~h}$ and rinsed in water for $1 \mathrm{~h}$. The sticks were submitted to microtensile test in a mechanical testing machine at $0.5 \mathrm{~mm} / \mathrm{min}$ until failure. Fracture pattern was analyzed using SEM. $\mu$ TBS values were calculated in MPa and submitted to analysis of variance ANOVA $(\alpha=0.05)$. The variance analysis showed that the 'MMP inhibitor' and 'degradation' factors ( $p=0.214$ and $p=0.093$, respectively) and interaction between the factors were not statistically significant $(p=0.143)$. Mixed failure predominated in all groups. In conclusion, the $2 \% \mathrm{CHX}$ and $\mathrm{NaF} 5000 \mathrm{ppm}$ presented similar $\mu \mathrm{TBS}$ of composite resin to laser-irradiated dentin before and after chemical degradation
\end{abstract}

\section{Introduction}

Preparation with Er:YAG laser has been proposed as an alternative technique for removing carious tissue and preparation of micro-cavities (1). Several advantages have been related to the use of laser irradiation in operative dentistry compared to conventional rotary instruments, such as a more conservative cavity design (2), antibacterial activity (3), decrease of enamel solubility (prevention of recurrent caries) (4), and mainly laser use provides more comfort to the patient due to the absence of vibration and a lower pain sensation with consequent decrease for local anesthesia compared to the use of conventional rotary instruments. A limitation of the laser use is the long time required for cavity preparation, generally, twice than with rotary instruments (5).

The bonding mechanism for irradiated dentin and also the impact of the Er:YAG lasers on the collagen fibers have not been completely clarified. Previous studies showed microstructural changes, microruptures and denaturation of collagen fibers $(6,7)$, which may affect the bonding mechanism between the resin materials and dentin, due the bond direct dependence on the interaction of resin monomers with the exposed collagen fibers (8).
The degradation of the bonding interface has a considerable influence on the clinical performance and survival of the resin composite restorations $(9,10)$. Studies have shown that matrix metalloproteinase (MMP) inhibitors, such as chlorhexidine (CHX) and more recently sodium fluoride $(\mathrm{NaF})$, are able to preserve the structural integrity of the hybrid layer and consequently improve the longevity of restorations (11-14).

The research was proposed due the lower bond stability of irradiated dentin to the adhesive systems and limited information concerning the effect of the MMP inhibitors to stabilize the degradation of this hybrid layer. Therefore, the aim of this laboratory study was to evaluate the effect of two MMP inhibitors - 2\% CHX and $\mathrm{NaF}$ (5000 ppm) - on microtensile bond strength ( $\mu \mathrm{TBS}$ ) of a composite resin to Er:YAG laser-irradiated dentin after chemical degradation of the bonded interface. The null hypothesis tested was that $\mathrm{NaF}(5000 \mathrm{ppm})$ is similar to $\mathrm{CHX}$ in the preservation of bonded interface.

\section{Material and Methods}

Experimental Design and Tested Groups

This laboratory study was designed to test the effect of 
the MMP inhibitors 2\% CHX (Clorhexidina S, FGM, Joinville, $\mathrm{SC}$, Brazil) (control group) and $\mathrm{NaF}$ (5000 ppm) (DaTerra, Ribeirão Preto, SP, Brazil) as well as degradation processes (24 $\mathrm{h}$ water storage and chemical degradation with 10\% $\mathrm{NaOCl}$ for $5 \mathrm{~h}$ ) on the $\mu \mathrm{TBS}$ between a composite resin and dentin treated with Er:YAG laser. The sample of the study comprised 40 human third molars assigned to 4 groups $(n=10)$. The response variable was $\mu$-TBS (MPa). Failure mode analysis of the bonded interface after $\mu$ TBS testing was carried out by scanning electron microscopy (SEM).

\section{Specimen Preparation}

Forty extracted intact human third molars were used according to the guidelines of the local Ethics Committee, under protocol number (31160914.6.0000.5419). The teeth roots were included in polyester resin, by a polyvinyl chloride (PVC) cylinder. The occlusal surface was removed with a diamond saw (Isomet 1000; Buehler, Lake Bluff, IL, USA) exposing a coronal dentin surface, which was ground in a polishing machine (Beta; Buehler) with wet \#600 sandpaper.

The dentin surfaces of all teeth were irradiated with Er:YAG laser $(260 \mathrm{~mJ} / 4 \mathrm{~Hz}$ ) (Twin Light, Fotona Medical Lasers, Ljubljana, Slovenia) with $0.81 \mathrm{~W}$ power, $47 \mathrm{~J} / \mathrm{cm}^{2}$ energy density and $163.5 \mathrm{~W} / \mathrm{cm}^{2}$ irradiance, scanning transversally and horizontally across the surface of the exposed dentin using a device that holds the laser pen in place. The laser beam was applied using a noncontact method, focused at a distance of $12 \mathrm{~mm}$ from the substrate with water spray of $1.5 \mathrm{~mL} / \mathrm{min}$ (9).

The specimens were etched with 35\% phosphoric acid (Etching gel, 3mas M ESPE, St. Paul, MN, USA) for $15 \mathrm{~s}$, rinsed for $30 \mathrm{~s}$ and dried for $30 \mathrm{~s}$ with air. Half of the specimens were rewetted with $1.5 \mathrm{~mL}$ of $2 \% \mathrm{CHX}$ (Clorhexidina $\mathrm{S}$, FGM, Joinville, SC, Brazil) with a micropipette (Labmate Soft, PZ HTL S.A., Warsaw, Poland) for $60 \mathrm{~s}$ and the excess removed with absorbent paper. The remaining specimens were rewetted with $\mathrm{NaF} 5000 \mathrm{ppm}$ in the same way as previously reported. The adhesive system (Single Bond 2; 3M ESPE) was applied following the manufacturer's instructions and cured with halogen light (Curing Light XL-3000; 3M Dental Products, St. Paul, MN, USA) for 10 s. A 4-mm-high plateau of composite resin (Filtek Z350; 3M ESPE) was built

Table 1. Mean (standard deviation) of microtensile bond strength (MPa) as function of the metalloproteinase inhibitor and degradation

\begin{tabular}{lcc}
\hline Group & $\begin{array}{c}\text { Water stored } \\
(24 \mathrm{~h})\end{array}$ & $\begin{array}{c}\text { Chemistry } \\
\text { degradation }\end{array}$ \\
\hline $2 \%$ chlorhexidine (control) & $20.5(5.2)$ & $16.5(5.0)$ \\
Sodium fluoride (5000 ppm) & $15.7(4.0)$ & $15.3(4.5)$ \\
\hline
\end{tabular}

There was no statistically significant difference between the groups ( $>>0.05)$. on adhesive-coated dentin surface using the incremental technique in four 1-mm layers.

\section{Degradation and $\mu$ TBS Test}

The specimens were vertically serially sectioned (Isomet 1000, Buehler Ltd.) into approximately 1-mm thick dentinresin slabs, and then rotated $90^{\circ}$ and sectioned again to obtain resin-dentin sticks with a rectangular cross-sectional area of $0.8-1 \mathrm{~mm}^{2}$. Four sticks were randomly selected from the central area of each sample. Half of the sticks groups were stored for $24 \mathrm{~h}$ in $37^{\circ} \mathrm{C}$ water before $\mu$-TBS. The other half were submitted to chemical degradation immersed in $10 \% \mathrm{NaOCl}$ aqueous solution (da Terra) for 5 $\mathrm{h}$ and rinsed in water for $1 \mathrm{~h}(15)$. The bonded surface area was calculated before each test using a digital caliper. The sticks were individually fixed to a jig using cyanoacrylate glue (Super Bonder Gel; Loctite, São Paulo, SP, Brazil) in a mechanical testing machine at $0.5 \mathrm{~mm} / \mathrm{min}$ (EMIC, São José dos Pinhais, PR, Brazil) and tested until failure. $\mu$ TBS values were calculated in $\mathrm{MPa}$. The teeth were considered the specimen numbers ( $n)$ per group $(n=10)$. Therefore, the mean value of $\mu$ TBS of the 4 sticks was considered the $\mu \mathrm{TBS}$ of the specimen. Data were subjected to analysis of variance ANOVA ( $\alpha=0.05)$.

All fractured sticks were dehydrated in increasing alcohol concentrations, as follows: $25 \%$ for $20 \mathrm{~min} ; 50 \%$ for 20 $\min ; 75 \%$ for $20 \mathrm{~min}$; 95\% for $20 \mathrm{~min}$; and 100\% for 60 min and mounted on aluminum stubs with carbon adhesive tape. The specimens were sputter-coated (SCD 050 sputter coater, BAL-TEC, Balzers, Liechtenstein) with pure gold and observed with a SEM, to examine the mode of failure of the debonded interfaces. Failure modes were classified as adhesive (in the bonding agent), cohesive in the composite resin, cohesive in dentin and mixed (remnants of composite

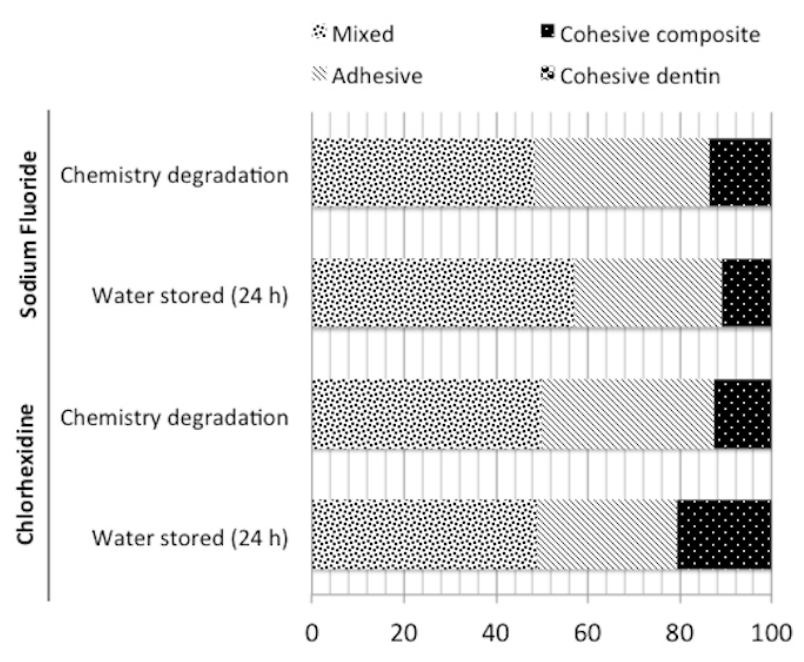

Figure 1. Distribution of failure modes (\%)among groups. 
and/or bonding agent on the dentin surface). The frequency of each mode was calculated as percentage.

\section{Results}

Mean values and standard deviation of the $\mu$ TBS are presented in Table 1. The variance analysis showed that the 'MMP inhibitor' and 'degradation' factors $(p=0.214$ and $p=0.093$, respectively) and interaction between the factors were not statistically significant ( $p=0.143$ ). The MMP inhibitor 2\% CHX and NaF 5000 ppm presented similar $\mu$ TBS before and after the chemical degradation.

Distribution of failure modes is presented in Figure 1. Mixed failures predominated in all groups. The number of cohesive failures was slightly higher in the group where $2 \% \mathrm{CHX}$ was used and the specimens were stored in water. Representative SEM images of mixed failure in all groups are illustrated in Figure 2.

\section{Discussion}

Most of the experiments designed to evaluate stability of the resin-dentin bond by enzyme inhibition have been performed with $\mathrm{CHX}$, a potent antimicrobial agent. CHX effectively inhibits MMP-2, -8 and $-9(13,16,17)$ and cysteine number of studies demonstrating its efficacy to decrease the degradation of the resin-dentin bonding interface.

Another MMP inhibitor presented in the literature is sodium fluoride. However, the mechanism of MMPs inhibition by NaFis not yet fully understood. Kato et al. (11) showed the inhibition of MMP- 2 and -9 by sodium fluoride, suggesting that the high electronegativity of the fluorine and heavy concentration of this mineral could release free cations to participate in the catalytic process. However, the study showed that irreversible inhibition was observed only in the fluoride at high concentration (5000 ppm); at lower concentrations $(250,500,1500 \mathrm{ppm}) \mathrm{MMP}$ inhibitory effect was considered to be reversible. In the present study the groups using different MMP inhibitors for rewetting the dentin presented similar results after water storage for $24 \mathrm{~h}$.

Accelerated aging is a relevant procedure to evaluate the long-term stability of the bonded interface (15). To simulate in the laboratory aging of adhesive restorations, a commonly used procedure is storing in $10 \% \mathrm{NaOCl}$. This is a nonspecific deproteinizing agent with tendency of creating superoxide radicals in aqueous solutions, therefore inducing oxidation phenomena, fragmenting the protein peptide chains $(15,21,22)$. The $10 \% \mathrm{NaOCl}$ may affect the resin-dentin bond by two different ways: first, degradation of the etched and non-resin-infiltrated layer; and second, by the collagen fibrils that were not properly resin-infiltrated and/or later exposed because of the resin dissolution by $10 \% \mathrm{NaOCl}$ (23). Therefore, collagen fibrils in the etched
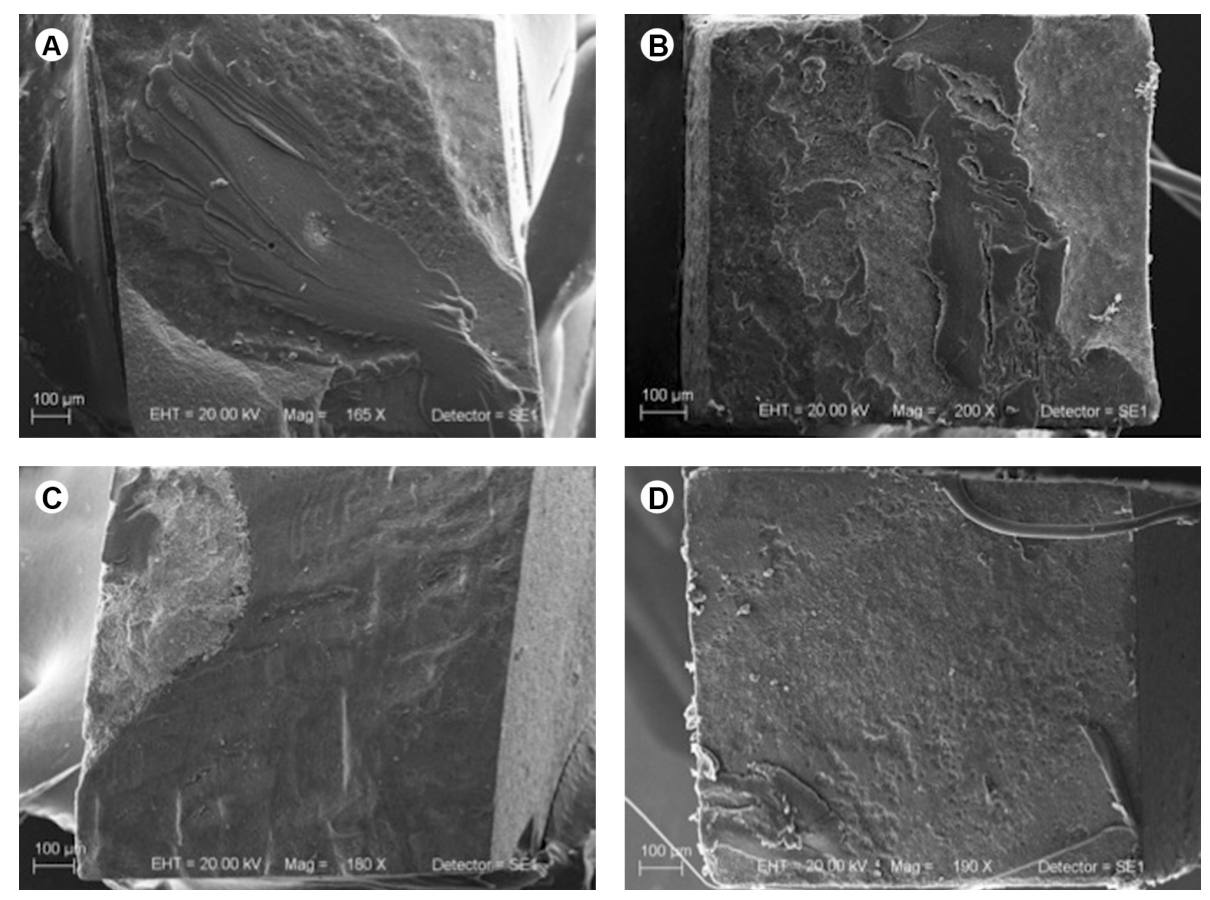

Figure 2. Representative SEM images $(20 \mathrm{kV}, 100 \mu \mathrm{m})$ of mixed failures predominant in all groups. A: $2 \%$ chlorhexidine/water storage; B: $2 \%$ Chlorhexidine/chemical degradation; C: sodium fluoride/water storage; D: Sodium fluoride/chemical degradation. 
dentin and the resin adhesive may have been affected by $10 \% \mathrm{NaOCl}$ action, leading to a rapid degradation of the resin-dentin layer $(15,24)$. In the current study, the results demonstrated that the MMP inhibitors, 2\% $\mathrm{CHX}$ and $\mathrm{NaF}(5000 \mathrm{ppm})$ were able to prevent chemical degradation of the adhesive interface, confirming the tested hypothesis. The predominance of mixed failures, especially in dentin irradiated with Er:YAG agree with the results of a previous study (25). Overall, no relevant change was observed in the failure mode among the groups.

It is possible to conclude that the MMP inhibitors, $2 \%$ $\mathrm{CHX}$ and $\mathrm{NaF} 5000 \mathrm{ppm}$ presented similar $\mu \mathrm{TBS}$ between Er:YAG laser irradiated dentin and composite resin after the chemical degradation. Further studies are suggested to evaluate longer times and different degradation forms to confirm the effectiveness of these inhibitors in the Er:YAG laser irradiated dentin.

\section{Resumo}

Este estudo avaliou o efeito dos inibidores de metaloproteinase, clorexidina 2\% e fluoreto de sódio (5000ppm), na resistência de união entre a dentina irradiada por laser Er:YAG e a resina composta após a degradação química da interface de união. A superfície oclusal de quarenta molares humanos hígidos $(n=10)$ foi removida expondo uma superficie de dentina, que foi polida, irradiada com laser Er:YAG, condicionada com ácido e seca. Vinte espécimes foram re-umedecidos com clorexidina 2\% (Grupo controle) e $20 \mathrm{com}$ fluoreto de sódio (5000 ppm). 0 sistema adesivo foi aplicado e um platô de resina composta fotopolimerizável de $4 \mathrm{~mm}$ de altura foi construido. Palitos de resina-dentina foram obtidos com secção transversal retangular (0,8-1 $\left.\mathrm{mm}^{2}\right)$. Eles foram armazenados em água $\left(24 \mathrm{~h}\right.$ a $\left.37^{\circ} \mathrm{C}\right)$ ou submetidos a degradação química. Para a degradação química, foram imersos em solução aquosa de hipoclorito de sódio a 10\% durante 5 horas e lavados em água durante $1 \mathrm{~h}$. Os palitos foram submetidos ao teste de microtração em uma máquina de ensaios mecânicos a 0,5 mm/min até a fratura. 0 padrão de fratura foi analisado em MEV. Os valores de resistência de união foram calculados em MPa e submetidos à análise de variância ANOVA $(\alpha=0,05)$. A análise de variância mostrou que os fatores inibidor de metaloproteinases e degradação ( $p=0,214$ e $p=0,093$, respectivamente), e a interação entre os fatores não foram estatisticamente significantes $(p=0,143)$. A predominância de falha mista foi detectada para todos os grupos. Em conclusão, a clorexidina a 2\% e fluoreto de sódio (ppm 5000) apresentaram resistência de união entre dentina irradiada e resina composta semelhante antes e após a degradação química.

\section{Acknowledgements}

The authors would like to acknowledge the São Paulo State Research Foundation - FAPESP for the financial support (Grant \#18868-7).

\section{References}

1. Buyukhatipoglu I, Secilmis A. The use of erbium: yttrium-aluminumgarnet laser in cavity preparation and surface treatment: 3-year followup. Eur J Dent 2015;9:284-287.

2. de Almeida Neves $A$, Coutinho $E$, Cardoso MV, Lambrechts $P$, Van Meerbeek $B$. Current concepts and techniques for caries excavation and adhesion to residual dentin. J Adhes Dent 2011;13:7-22.

3. Turkun M, Turkun LS, Celik EU, Ates M. Bactericidal effect of Er,Cr:YSGG laser on Streptococcus mutans. Dent Mater J 2006;25:81-86.

4. Cecchini RC, Zezell DM, de Oliveira E, de Freitas PM, Eduardo C de P. Effect of Er:YAG laser on enamel acid resistance: morphological and atomic spectrometry analysis. Lasers Surg Med 2005;37:366-372.

5. Keller U, Hibst R, Geurtsen W, Schilke R, Heidemann D, Klaiber B, et al.. Erbium:YAG laser application in caries therapy. Evaluation of patient perception and acceptance. J Dent 1998;26:649-656.

6. Ceballo L, Toledano M, Osorio R, Tay FR, Marshall GW. Bonding to ErYAG-laser-treated dentin. J Dent Res 2002;81:119-122.

7. Aranha AC, De Paula Eduardo C, Gutknecht N, Marques MM, Ramalho KM, Apel C. Analysis of the interfacial micromorphology of adhesive systems in cavities prepared with Er,Cr:YSGG, Er:YAG laser and bur. Microsc Res Tech 2007;70:745-751.

8. Schein MT, Bocangel JS, Nogueira GE, Schein PA. SEM evaluation of the interaction pattern between dentin and resin after cavity preparation using ER:YAG laser. J Dent 2003;31:127-135.

9. Amaral FL, Colucci V, Palma-Dibb RG, Corona SA. Assessment of in vitro methods used to promote adhesive interface degradation: a critical review. J Esthet Restor Dent 2007;19:340-353; discussion 354.

10. Frassetto A, Breschi L, Turco G, Marchesi G, Di Lenarda R, Tay FR, et al.. Mechanisms of degradation of the hybrid layer in adhesive dentistry and therapeutic agents to improve bond durability-A literature review. Dent Mater 2016;32:e41-e53.

11. Kato MT, Bolanho A, Zarella BL, Salo T, Tjaderhane L, Buzalaf MA. Sodium fluoride inhibits MMP-2 and MMP-9. J Dent Res 2014;93:74-77.

12. Carrilho MR, Geraldeli $S$, Tay F, de Goes MF, Carvalho RM, Tjaderhane $L$, et al.. In vivo preservation of the hybrid layer by chlorhexidine. J Dent Res 2007;86:529-533.

13. Pashley DH, Tay FR, Yiu C, Hashimoto M, Breschi L, Carvalho RM, et al.. Collagen degradation by host-derived enzymes during aging. J Dent Res 2004;83:216-221.

14. Carrilho MR, Carvalho RM, de Goes MF, di Hipolito V, Geraldeli S, Tay FR, et al.. Chlorhexidine preserves dentin bond in vitro. J Dent Res 2007;86:90-94.

15. Toledano M, Cabello I, Yamauti M, Giannini M, Aguilera FS, Osorio E, et al.. Resistance to degradation of resin-dentin bonds produced by onestep self-etch adhesives. Microsc Microanal 2012;18:1480-1493.

16. Gendron R, Grenier D, Sorsa T, Mayrand D. Inhibition of the activities of matrix metalloproteinases 2,8 , and 9 by chlorhexidine. Clin Diagn Lab Immunol 1999;6:437-439.

17. Hebling J, Pashley DH, Tjaderhane L, Tay FR. Chlorhexidine arrests subclinical degradation of dentin hybrid layers in vivo. J Dent Res 2005;84:741-746.

18. Scaffa PM, Vidal CM, Barros N, Gesteira TF, Carmona AK, Breschi L, et al.. Chlorhexidine inhibits the activity of dental cysteine cathepsins. J Dent Res 2012;91:420-425.

19. Breschi L, Mazzoni A, Nato F, Carrilho M, Visintini E, Tjaderhane L, et al.. Chlorhexidine stabilizes the adhesive interface: a 2-year in vitro study. Dent Mater 2010;26:320-325

20. Breschi L. Chlorhexidine application to stabilize the adhesive interface: why and how? J Adhes Dent 2013;15:492.

21. Osorio R, Toledano M, Osorio E, Aguilera FS, Tay FR. Effect of load cycling and in vitro degradation on resin-dentin bonds using a self-etching primer. J Biomed Mater Res A 2005;72:399-408.

22. Monticelli $F$, Osorio $R$, Pisani-Proenca J, Toledano M. Resistance to degradation of resin-dentin bonds using a one-step HEMA-free adhesive. J Dent 2007;35:181-186.

23. Toledano M, Osorio R, Albaladejo A, Aguilera FS, Osorio E. Differential effect of in vitro degradation on resin-dentin bonds produced by selfetch versus total-etch adhesives. J Biomed Mater Res A 2006;77:128135.

24. Yoshida $E$, Hashimoto $M$, Hori $M$, Kaga $M$, Sano $H$, Oguchi $H$. Deproteinizing effects on resin-tooth bond structures. J Biomed Mater Res B Appl Biomater 2004;68:29-35.

25. Galafassi D, Scatena C, Colucci V, Rodrigues-Junior AL, Campos Serra M, Corona SA. Long-term chlorhexidine effect on bond strength to Er:YAG laser irradiated-dentin. Microsc Res Tech 2014;77:37-43.

Received February 15, 2016 Accepted May 17, 2016 